\title{
Locally isolated yeasts from Malaysia: Identification, phylogenetic study and characterization
}

\author{
Siti Nurbaya Oslan1, Abu Bakar Salleh ${ }^{1,3 凶}$, Raja Noor Zaliha Raja Abd Rahman ${ }^{1,3}$, Mahiran \\ Basri2,3 and Adam Leow Thean Chor 1,3 \\ 'Faculty of Biotechnology and Biomolecular Sciences; ${ }^{2}$ Faculty of Science; ${ }^{3}$ nnstitute of Bioscience, Universiti Putra Malaysia, Serdang, Selangor,
} Malaysia

Yeasts are a convenient platform for many applications. They have been widely used as the expression hosts. There is a need to have a new yeast expression system to contribute the molecular cloning demands. Eight yeast isolates were screened from various environment sources and identified through ribosomal DNA (rDNA) Internal Transcribed Spacer (ITS). Full sequence of the rDNA ITS region for each isolate was BLASTed and phylogenetic study was constructed by using MEGA4. Among the isolates, isolate WB from 'ragi' (used to ferment carbohydrates) could be identified as a new species in order Saccharomycetales according to rDNA ITS region, morphology and biochemical tests. Isolate SO (from spoiled orange), RT (rotten tomato) and RG (different type of 'ragi') were identified as Pichia sp. Isolates R1 and R2, S4 and S5 (from the surrounding of a guava tree) were identified as Issatchenkia sp. and Hanseniaspora sp., respectively. Geneticin, $50 \mu \mathrm{g} / \mathrm{mL}$, was determined to be the antibiotic marker for all isolates excepted for isolates RT and SO which used $500 \mu \mathrm{g} / \mathrm{mL}$ and $100 \mu \mathrm{g} /$ $\mathrm{mL}$ Zeocin, respectively. Intra-extracellular proteins were screened for lipolytic activity at $30^{\circ} \mathrm{C}$ and $70^{\circ} \mathrm{C}$. Thermostable lipase activity was detected in isolates RT and R1 with $0.6 \mathrm{U} / \mathrm{mg}$ and $0.1 \mathrm{U} / \mathrm{mg}$, respectively. In conclusion, a new yeast-vector system for isolate WB can be developed by using phleomycin or geneticin as the drugs resistance marker. Moreover, strains RT and R1 can be investigated as a novel source of a thermostable lipase.

Key words: yeast, phylogenetic study, characterization study

Received: 25 August, 2011; revised: 15 December, 2011; accepted: 27 February, 2012; available on-line: 11 May, 2012

\section{INTRODUCTION}

Yeasts have played important roles in industrial development for thousands of years. Various species of yeast have been used in diverse applications such as in food industries (alcoholic fermentation), expression system, and as models for the study of higher eukaryotes. 'Ragi' is a popular traditional yeast 'cake' used as a starter in making local Malaysian food such as 'tapai' (fermented rice or cassava) and 'tempe' (soybean fermented into a soybean cake). Besides that, it has been used in baking, brewing and ethanol production (Akada, 2002). Yeasts have also been used as one of the most powerful expression system. Furthermore, like bacteria, yeasts are unicellular eukaryote which is simple to cultivate on inexpensive growth media. Unfolded and misfold protein are less risky in yeast system. Yeasts offer various advan- tages for heterologous genes expression. They can grow to ultrahigh cell densities (Romanos et al., 1992), secrete proteins extracellularly, grow under non-selective conditions, and perform post-translational modifications such as glycosylation, disulphide bond formation, multimeric assembly and endoproteolytic cleavage (Hadfield et al., 1993).

Concerned baker's yeast, Saccharomyces cerevisiae, huge numbers of applications and studies have been conducted particularly as a host for heterologous expression of proteins. Proteins expressed by $S$. cerevisiae are safe to humans due to its Generally Recognized as Safe (GRAS) status (Gellissen \& Hollenberg, 1997). In recent years, there has been an increasing interest in using other yeast expression systems for protein production. Other widely used expression hosts include Pichia pastoris (Shi et al., 2007), Hansenula polymorpha (Voronovsky et al., 2009), Yarrowia lipolytica (Gellissen et al., 2005) and Arxula adeninivorans (Steinborn et al., 2007).

Since there is a lot of a demand for yeasts, identification and characterization of new yeast strain should be conducted to meet those needs. Yeast identification can be conducted using molecular approach and biochemical tests. Earlier classification of yeast had used lower taxonomic level by looking only at sexual state, hyphae and pseudohyphae, sugar fermentation and types of carbon and nitrogen sources compounds (Suh et al., 2006). In the present study, PCR amplification of the ITS1-5.8SITS2 regions of the rDNA was applied for identification of locally isolated yeast (Pramateftaki et al., 2000). Phylogenetic study and characterization of the yeast may help in determination of its GRAS status. Eight isolates were further characterized morphologically and biochemically on possible sources of thermostable lipases and hosts for heterologous protein expression.

\section{MATERIALS AND METHODS}

Plasmid and strains. pGEM ${ }^{\circledR}-\mathrm{T}$ Vector was used to clone the rDNA regions. Escherichia coli strain JM109 was used for plasmid propagation and maintenance. The plasmid and the E. coli strain were purchased from Promega.

e-mail: abubakar@biotech.upm.edu.my

Abbreviations: rDNA, ribosomal DNA; ITS, internal transcribed spacer; MEGA, molecular evolutionary genetics analysis; GRAS, generally recognized as safe; LB, Luria-Bertani; SDA, Sabouraud dextrose agar; YPD, yeast peptone dextrose; $\mathrm{dH}_{2} \mathrm{O}$, distilled water; BLAST, basic alignment search tools; DSM-DSMZ, Deutsche Sammlung von Mikroorganismen und Zellkulturen GmbH; NCBI, National Center for Biotechnology Information; PCR, polymerase chain reaction. 
Media. Luria-Bertani broth (LB) and agar were used to grow the bacterium. Sabouraud dextrose agar (SDA) and yeast peptone dextrose (YPD) agar $[1 \%(\mathrm{w} / \mathrm{v})$ Yeast Extract, 2\% Peptone, 2\% (w/v) Dextrose, 2\% (w/v) Agar) were used for yeast growth.

Isolation and identification of yeast. Thirteen isolates were collected from various locations from Malaysia for yeast isolation. Yeasts were isolated from different types of 'ragi', water, soil, spoiled orange and rotten guava (Syzygium sp.). Serial dilution in sterile $\mathrm{dH}_{2} \mathrm{O}$ was prepared accordingly for each isolate. Then, $100 \mu \mathrm{L}$ diluents were spread onto SDA and YPD agar for 2-4 days at $30^{\circ} \mathrm{C}$ until colonies formed. Oval, elevated, and whitish colonies were examined under light microscope. The colonies in which budding cells were seen were inoculated into $10 \mathrm{~mL}$ of YPD. The isolates were incubated at $30^{\circ} \mathrm{C}, 250 \mathrm{rpm}$, for $24 \mathrm{~h}$ prior to DNA extraction by using QIAquick ${ }^{\circledR}$ Genomic Extraction Kit (Qiagen, Germany).

PCR amplification of the ITS1-5.8S-ITS2 regions of the nuclear ribosomal gene complex was conducted for species identification. Primers for Internal Transcribed Spacer (ITS) sequence were synthesized according to fungus universal primer (Pramateftaki et al., 2000), Forward ITS1: 5'-GTCTCCGTTGGTGAACCAGC-3', Reverse ITS4: 5'-ATATGCT'TAAGT'TCAGCGGGT-3'. Amplification processes were carried out in a reaction mixture $(100 \mu \mathrm{L})$ containing $5 \mu \mathrm{L}(50-100 \mathrm{ng})$ of DNA template, $3 \mu \mathrm{L}(10 \mathrm{pmol} / \mu \mathrm{L})$ of each forward and reverse primers, $2 \mu \mathrm{L}$ of $10 \mathrm{mM}$ dNTP mix, $8 \mu \mathrm{L}$ of 25 $\mathrm{mM} \mathrm{MgCl} 2,2 \mu \mathrm{L}$ of $1 \mathrm{U} / \mu \mathrm{L}$ Taq DNA polymerase, 10 $\mu \mathrm{L}$ of $10 \times$ PCR buffer (MBI Fermentas, USA) and 67 $\mu \mathrm{L}$ of distilled water. The reaction parameters were as follows: initial denaturation for $5 \mathrm{~min}$ at $95^{\circ} \mathrm{C}$, followed by 30 cycles of $95^{\circ} \mathrm{C}$ for $1 \mathrm{~min}, 60^{\circ} \mathrm{C}$ for $1 \mathrm{~min}$, and $72^{\circ} \mathrm{C}$ for $5 \mathrm{~min}$, and a final $5 \mathrm{~min}$ extension at $72^{\circ} \mathrm{C}$ using a gradient thermocycler (Gragdient PCR CGI-96, Rcorbett Research).

The $18 \mathrm{~S}$ rDNA was amplified by using primers from previous study (Medlin et al., 1988); Forward 16S-like rDNA: 5'-AACCTGGGTTGATCCTGCCAGT-3', Reverse 16S-like rDNA: 5'-TGATCCT'TCTGCAGGT'TCACCTAC-3'. The reaction mixture was set as described previously. The reaction parameters were as follows: initial denaturation for $5 \mathrm{~min}$ at $94^{\circ} \mathrm{C}$, followed by 30 cycles of $94^{\circ} \mathrm{C}$ for $1 \mathrm{~min}, 63^{\circ} \mathrm{C}$ for $2.5 \mathrm{~min}$, and $72^{\circ} \mathrm{C}$ for $7 \mathrm{~min}$, and a final $20 \mathrm{~min}$ extension at $72^{\circ} \mathrm{C}$. The amplicon was purified using GeneAll ${ }^{\mathbb{B}}$ Expin $^{\mathrm{TM}}$ Combo GP according to the manufacturer's instructions. Then, the amplicon was cloned into pGEMT vector for sequencing. The plasmid was extracted by using GeneAll ${ }^{\circledR}$ Exprep $^{\mathrm{TM}}$ Plasmid Quick. The sequencing results were analyzed using Molecular Evolutionary Genetics Analysis software version 4.0 (MEGA4) and Basic Alignment Search Tools (BLAST) (http://www.ncbiblast.com). A cladogram tree for each isolate was constructed by using MEGA4.

Determination of antibiotic resistance. Yeast isolates were streaked on YPD agar and incubated at $30^{\circ} \mathrm{C}$ for 3 days. Subsequently, single colony was patched on YPD plate supplemented with different types of antibiotics at recommended concentrations. All the antibiotics were purchased from Invivogen with the exception for Zeocin, which was from Invitrogen, USA. The antibiotics and their working concentrations were as follows; Blasticidine-S (5 $\mu \mathrm{g} / \mathrm{mL})$, Phleomycin $(10 \mu \mathrm{g} / \mathrm{mL})$, Zeocin $(100 \mu \mathrm{g} / \mathrm{mL})$, Hygromycin B $(50 \mu \mathrm{g} / \mathrm{mL})$, Geneticin $(500 \mu \mathrm{g} / \mathrm{mL})$, and Puromycin $(5 \mu \mathrm{g} / \mathrm{mL})$. Second screening for antibiotic resistance was carried out using higher concentrations of Blasticidine-S $(50 \mu \mathrm{g} / \mathrm{mL})$, Ze- ocin $(500 \mu \mathrm{g} / \mathrm{mL})$, Phleomycin $(25 \mu \mathrm{g} / \mathrm{mL})$, and Puromycin $(25 \mu \mathrm{g} / \mathrm{mL})$. Furthermore, lower amount of Hygromycin B $(25 \mu \mathrm{g} / \mathrm{mL})$ and Geneticin $(50 \mu \mathrm{g} / \mathrm{mL})$ was used. These amounts were expected to be sufficient for the selections.

Screening for lipase activity. A single colony was inoculated into $10 \mathrm{~mL}$ of YPD broth and incubated at $30^{\circ} \mathrm{C}$ for $24 \mathrm{~h}$ in an incubator shaker of $250 \mathrm{rpm}$. Then, $1 \mathrm{~mL}$ of culture was transferred into $100 \mathrm{~mL}$ of YPD broth in $500 \mathrm{~mL}$ shake flask. The cells were cultivated for three days under the same conditions. Then, a 20 $\mathrm{mL}$ culture was harvested by centrifugation at $3000 \times \mathrm{g}$ for $10 \mathrm{~min}$ at $4^{\circ} \mathrm{C}$. The supernatant was collected and the pellet was resuspended in $10 \mathrm{~mL}$ of $50 \mathrm{mM}$ phosphate buffer $\mathrm{pH} 7$. The pellet was sonicated at 30 watt with a Branson Sonifier ${ }^{\mathbb{R}}$ ultrasonic cell disruptor (DIGITAL Sonifier $^{\circledR}$ UNIT Model S-250D) for 5 min. After breaking the cells, the homogenate was centrifuged at $10000 \times g$ for $10 \mathrm{~min}$ at $4^{\circ} \mathrm{C}$. The clear cell lysate and culture medium were assayed for intracellular and extracellular lipase activity at $30^{\circ} \mathrm{C}$ and $70^{\circ} \mathrm{C}$ according to Kwon \& Rhee (1986) method. An emulsion of olive oil (Bertoli, Italy) and $50 \mathrm{mM}$ phosphate buffer pH7 (1:1) supplemented with $20 \mu \mathrm{L}$ of $20 \mathrm{mM} \mathrm{CaCl}_{2}$ was used as substrate. Standard curve of fatty acid released was prepared by using oleic acid. One unit of lipase activity was defined as the amount of activity releasing 1 mole of fatty acid per minute.

Characterization of yeast WB. Single colony of isolate WB was inoculated in YPD slant agar and incubated at $30^{\circ} \mathrm{C}$ for $72 \mathrm{~h}$ and sent to DSM-Deutsche Sammlung von Mikroorganismen und Zellkulturen $\mathrm{GmbH}-$ the German Resource Centre for Biological Material (DSMZ) for yeast identification.

\section{RESULTS}

\section{Identification of yeast species}

Yeast isolates were collected from various environmental spots in Malaysia. SDA and YPD agar were used to screen the yeast colonies. The acidic condition with pH5.6 of SDA medium inhibits many species of bacteria, therefore promoting yeast and fungal growth. Selected colonies were observed under light microscope for budding cells, a characteristic of budding yeasts. Out of thirteen isolates, eight showed typically yeast morphology. The eight isolates were subjected to total genomic DNA extraction and the ITS region for each isolates was amplified giving $400-800$ bp of PCR product (Fig. 1),

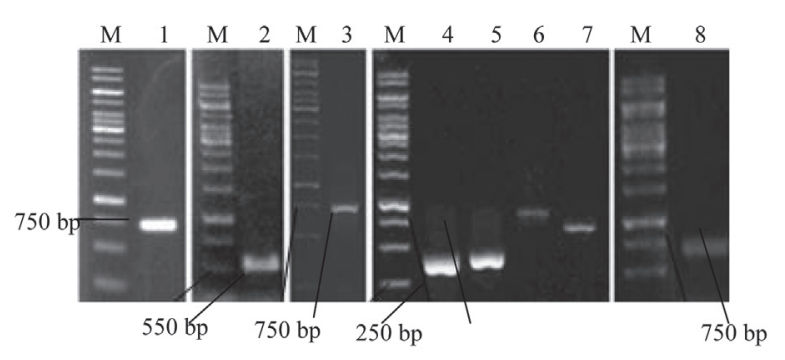

Figure 1. rDNA ITS region of locally isolated yeasts from Malaysia.

The PCR product was electrophoressed on $1 \%(\mathrm{w} / \mathrm{v})$ agarose gel and stained with GelRed. M: Marker Gene Ruler $1 \mathrm{~kb}$ DNA ladder; Lane 1: Isolate WB; Lane 2: Isolate SO; Lane 3: Isolate R1; Lane 4: Isolate S4; Lane 5: Isolate S5; Lane 6: Isolate R1; Lane 7: Isolate RT; and Lane 8: Isolate RG. 
Table 1. Screening for antibiotic resistance of locally isolated yeasts.

Different concentrations of antibiotics were used. $[X]$ represents no growth and $[\sqrt{ }]$ represents growth on antibiotics plates.

\begin{tabular}{|c|c|c|c|c|c|c|c|c|c|c|c|c|c|}
\hline \multirow[t]{2}{*}{ Isolate } & \multicolumn{2}{|c|}{$\begin{array}{l}\text { Blasticidine } \\
(\mu \mathrm{g} / \mathrm{mL})\end{array}$} & \multicolumn{2}{|c|}{$\begin{array}{l}\text { Phleomycin } \\
(\mu \mathrm{g} / \mathrm{mL})\end{array}$} & \multicolumn{2}{|c|}{$\begin{array}{l}\text { Zeocin } \\
(\mu \mathrm{g} / \mathrm{mL})\end{array}$} & \multicolumn{2}{|c|}{$\begin{array}{l}\text { Hygromycin } \\
(\mu \mathrm{g} / \mathrm{mL})\end{array}$} & \multicolumn{2}{|c|}{$\begin{array}{l}\text { Geneticin } \\
(\mu \mathrm{g} / \mathrm{mL})\end{array}$} & \multicolumn{2}{|c|}{$\begin{array}{l}\text { Puromycin } \\
(\mu \mathrm{g} / \mathrm{mL})\end{array}$} & \multirow{2}{*}{$\begin{array}{l}\text { YPD control } \\
-\end{array}$} \\
\hline & 5 & 50 & 10 & 25 & 100 & 500 & 25 & 50 & 50 & 500 & 5 & 25 & \\
\hline WB & $\sqrt{ }$ & $\sqrt{ }$ & $\sqrt{ }$ & $x$ & $\sqrt{ }$ & $x$ & $\sqrt{ }$ & $x$ & $X$ & $x$ & $\sqrt{ }$ & $\sqrt{ }$ & $\sqrt{ }$ \\
\hline $\mathrm{R} 1$ & $\sqrt{ }$ & $\sqrt{ }$ & $\sqrt{ }$ & $\sqrt{ }$ & $\sqrt{ }$ & $x$ & $X$ & $x$ & $x$ & $x$ & $\sqrt{ }$ & $\sqrt{ }$ & $\sqrt{ }$ \\
\hline $\mathrm{R} 2$ & $\sqrt{ }$ & $\sqrt{ }$ & $\sqrt{ }$ & $\sqrt{ }$ & $\sqrt{ }$ & $\sqrt{ }$ & $x$ & $X$ & $x$ & $X$ & $\sqrt{ }$ & $\sqrt{ }$ & $\sqrt{ }$ \\
\hline RT & $\sqrt{ }$ & $\sqrt{ }$ & $\sqrt{ }$ & $\sqrt{ }$ & $\sqrt{ }$ & $x$ & $\sqrt{ }$ & $\sqrt{ }$ & $\sqrt{ }$ & $\sqrt{ }$ & $\sqrt{ }$ & $\sqrt{ }$ & $\sqrt{ }$ \\
\hline SO & $\sqrt{ }$ & $\sqrt{ }$ & $\sqrt{ }$ & $\sqrt{ }$ & $x$ & $x$ & $x$ & $x$ & $\sqrt{ }$ & $x$ & $\sqrt{ }$ & $\sqrt{ }$ & $\sqrt{ }$ \\
\hline S4 & $\sqrt{ }$ & $\sqrt{ }$ & $x$ & $x$ & $X$ & $x$ & $x$ & $x$ & $x$ & $X$ & $\sqrt{ }$ & $\sqrt{ }$ & $\sqrt{ }$ \\
\hline S5 & $\sqrt{ }$ & $\sqrt{ }$ & $X$ & $X$ & $X$ & $x$ & $\sqrt{ }$ & $\sqrt{ }$ & $x$ & $X$ & $\sqrt{ }$ & $\sqrt{ }$ & $\sqrt{ }$ \\
\hline $\mathrm{RG}$ & $\sqrt{ }$ & $\sqrt{ }$ & $X$ & $X$ & $X$ & $X$ & $\sqrt{ }$ & $X$ & $\sqrt{ }$ & $X$ & $\sqrt{ }$ & $\sqrt{ }$ & $\sqrt{ }$ \\
\hline
\end{tabular}

within the range suggested by Pramateftaki et al., (2000). Furthermore, the result shows different sizes of the ITS region which can be for species identification (Korabecna, 2007; Pramateftaki et al., 2000).

The amplicons were sequenced and the sequences were analyzed using BLAST at NCBI. Isolate WB shows 93\% similarity to Saccharomycodes sinensis, isolates S4 and S5 show $96 \%$ similarity to Issatchenkia hanoiensis. These similarity values are below the threshold for genus and species identification, therefore they could be a new genus or species. Isolates SO, RT and RG were closely related to Pichia guilliermondii with 99\% similarity. R1 and R2 proved that they were $99 \%$ similar to Hanseniaspora opuntiae and Hanseniaspora thailandica, respectively. R1, R2, S4 and S5 were isolated from the surrounding of a guava tree. Full sequences of the ITS regions of WB, SO, RT, RG, R1, R2, S4 and S5 have been submitted to GeneBank under the following accession numbers: JN084124, JN084128, JQ073892, JN559754, JN084125, JN084126, JN084127, JN559755.

Phylogenetic study for the isolates was conducted and the cladogram tree obtained by using MEGA4 (Tamura et al., 2007) is shown in Fig. 2. The evolutionary history was inferred using the Neighbor-Joining method (Saitou \& Nei, 1987). The percentage of replicate trees in which the associated taxa clustered together in the bootstrap test (1000 replicates) are shown next to the branches (Felsenstein, 1985). The tree is drawn to scale, with branch lengths in the same units as those of the evolutionary distances used to infer the phylogenetic tree. The evolutionary distances were computed using the Maximum Composite Likelihood method (Tamura et al., 2004) and are in the units of the number of base substitutions per site. All positions containing alignment gaps and missing data were eliminated only in pairwise sequence comparisons (Pairwise deletion option). There were a total of 844 positions in the final dataset.

To evaluate the reliability of the inferred tree, the option of doing a bootstrap analysis is allowed. A bootstrap value is attached to each branch, and this value is a measure of confidence in this branch. The maximum value is 100. Figure 2 illustrates that isolates RG, SO and RT gave 100 bootstrap values to Pichia guilliermondii. Nevertheless, isolates R1 and R2 the bootstrap value was 98 to Hanseniaspora sp. Isolate S4 and S5 also showed 100 bootstrap values to Issatchenkia hanoiensis. According to this phylogenetic study, isolate WB was completely separated from other reference genera. The constructed clad- ogram tree showed that the phylogenetic position of WB sample is closely related to $S d$. sinensis IFO $10111^{\mathrm{T}}$ with a bootstrap value of 99 for the ITS region therefore it was separated from any of other yeast species (Yamazaki et al., 2005). Further identification of isolate WB and characterization for all isolates were performed towards development as potential expression host.

\section{Determination of antibiotic resistance}

Screening for antibiotic selection markers for the isolates is shown in Table 1. Blasticidine-S and puromycin could not be used as the drug resistance markers for these particular isolates. Geneticin $50 \mu \mathrm{g} / \mathrm{mL}$ was found to be the antibiotic selection marker for all isolates excepted for isolates RT and SO which used $500 \mu \mathrm{g} / \mathrm{mL}$ and $100 \mu \mathrm{g} / \mathrm{mL}$ Zeocin, respectively. Hygromycin B and

Table 2. Carbon and nitrogen sources utilized by WB strain.

$[+]$ represents growth and [-] represents no growth on tested carbon and nitrogen sources.

\begin{tabular}{lllll}
\hline Anaerobic: & Glucose & + & & \\
\hline Aerobic : & & & & \\
\hline & Glucose & + & a-methylglycoside & - \\
& Galactose & + & Salicin & - \\
& Sorbose & - & Cellobiose & - \\
& Rhamnose & - & Maltose & - \\
& Dulcit & - & Lactose & - \\
& Inositol & - & Melibiose & - \\
& Mannitol & - & Sucrose & - \\
& Sorbitol & - & Trehalose & - \\
Glycerol & - & Inulin & - \\
& Erythritol & - & Melezitose & - \\
D-Arabinose & - & Raffinose & - \\
L-Arabinose & - & Starch & - \\
Ribose & - & Xylitol & - \\
D-Xylose & - & Gluconate & - \\
L-Xylose & - & 2-keto-Gluconate & + \\
Adonitol & - & 5-keto-Gluconate & - \\
Nitrate & - & & \\
\hline
\end{tabular}




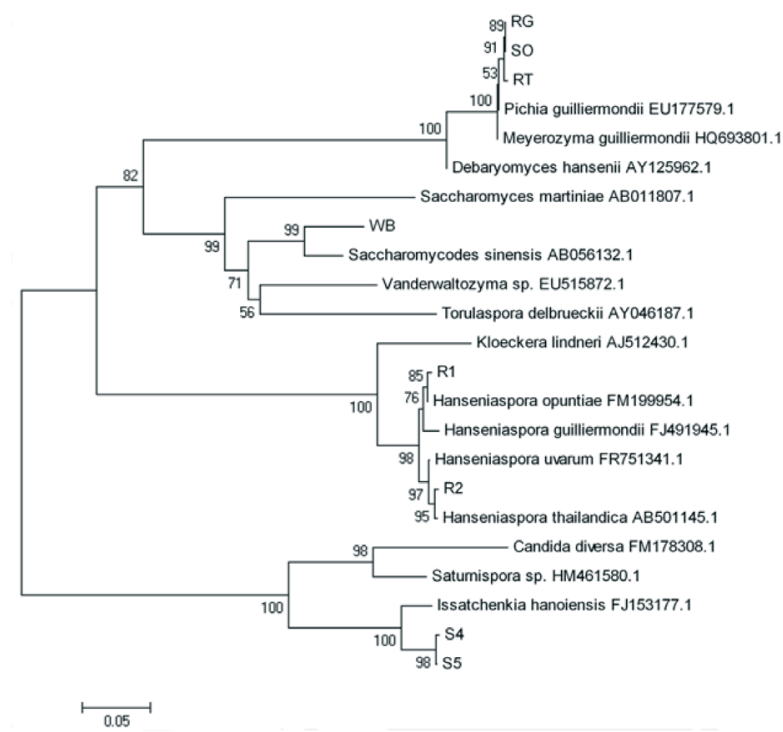

Figure 2. Phylogenetic study of locally isolated yeasts.

The cladogram tree was constructed by using MEGA4. NeighborJoining method with 1000 bootstrap value was used to draw the tree. Isolates WB, R1, R2, RT, RG, S4, S5, and SO were located at particular branch.

Geneticin had been used as dominant selectable markers for yeasts and prokaryotes cells. These antibiotics were used to disrupt ribosomal function and cause translational errors (Kaster et al., 1984; Millerioux et al., 2011). Zeocin had been used as dominant selection marker in Pichia pastoris. Sunga et al. (2008) had used different concentration of Zeocin for screening the hyper-resistance transformants. Isolates S4 and S5 were determined to be in Issatchenkia sp., however isolate S5 could be selected by using Hygromycin B. The Pichia isolates (RT, SO, and RG) had shown different pattern of selection markers. This result proved that the isolate could be a new species or strain.

\section{Lipase activity of yeast isolates}

Lipase assay was performed at two different temperatures $\left(30^{\circ} \mathrm{C}\right.$ and $\left.70^{\circ} \mathrm{C}\right)$ for both extracellular and intracellular proteins. Screening for lipase at $30^{\circ} \mathrm{C}$ was conducted to identify the host that produced a lipase, whilst $70^{\circ} \mathrm{C}$ was used as an indicator of a thermostable lipase.

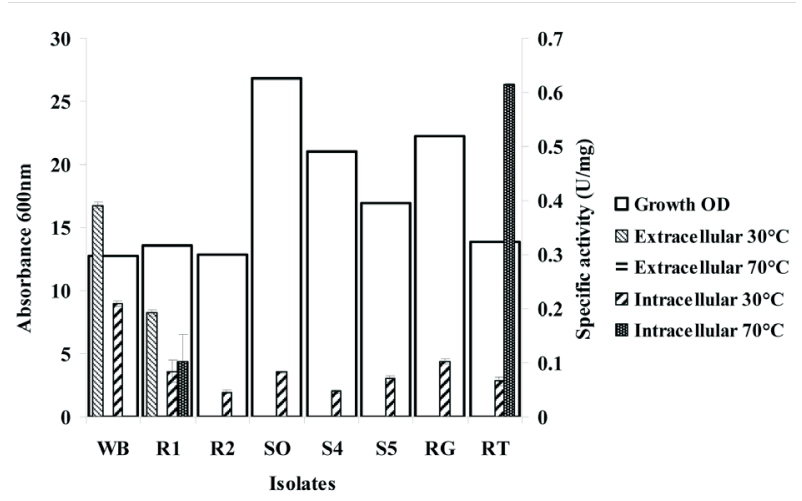

Figure 3. Screening for intra-extracellular lipase activity from local yeasts after 3 days of cultivation.

Lipase assay was performed at $30^{\circ} \mathrm{C}$ and $70^{\circ} \mathrm{C}$. Growth $\mathrm{OD}$ was taken with $10 \times$ dilution in YPD medium.
As shown, no thermostable extracellular lipase activity was detected in any of the isolates after three days of cultivation (Fig. 3). Low level of intracellular lipase activity $\left(30^{\circ} \mathrm{C}\right)$ was found in all isolates. However, isolates R1 and RT produced intracellular thermostable lipase with $0.1 \mathrm{U} / \mathrm{mg}$ and $0.6 \mathrm{U} / \mathrm{mg}$, respectively. In this study, we tried to quantify the native lipases produced from local yeasts. Yarrowia lipolytica (Vakhlu \& Kour, 2006) and Candida rugosa (Fadiloglu \& Erkmen, 2002) were found to produce their own lipases. Yarrowia lipolytica has been used to clone heterologous genes under the control of its strong promoters (Madzak et al., 2004).

\section{Characterization of isolate WB: 18S rDNA identification}

From the characterization study, isolate WB was selected for further investigation towards development as an applicable host. Isolate WB was safe to be used in many applications due to its origin from food. It showed no thermostable intracellular or extracellular lipolytic activity. Further identification through $18 \mathrm{~S}$ rDNA was performed for confirmation. This fragment had been used by Medlin et al., (1988) for 16S-like rDNA identification. The rDNA sequence was analyzed using NCBI BLAST and the result showed that $18 \mathrm{~S}$ rDNA of yeast WB was 98\% similar to Saccharomyces dairenensis. Since molecular approaches by using ITS and rDNA for isolate WB were divergent, further characterization study was conducted.

\section{Characterization of isolate WB: Morphology and biochemical test}

Morphological and biochemical tests on isolate WB were conducted by sending the isolate to DSMZ. The report shows that the colony morphology appeared as creme-coloured and butyrous on potato dextrose agar. The blastospores were globose-ellipsoidal with a pseudomycelium. True mycelium was totally absent from the isolate. Asci presented with one or two globose ascospores. Isolate WB did not show peculiar bipolar budding like Saccharomyces sp.

Effects of carbon and nitrogen sources were investigated (Table 2). Isolate WB showed a weak growth at $37^{\circ} \mathrm{C}$ and was totally inhibited with $\mathrm{N}$-acetylglucosamine. Different kind of carbon compounds tested revealed that only glucose, galactose and 2-keto gluconate could be used as energy sources. Moreover, only glucose can support the WB growth both aerobic and anaerobically. These result proved that very limited energy sources can be used by the yeast. Saccharomyces dairenensis should be able to utilize Trehalose, however this isolate WB was clearly negative with this particular carbon source. According to these findings, DSMZ suggested that the WB species could be Torulaspora delbrueckii.

\section{DISCUSSION}

Generally, Saccharomyces sp. yeast can be found in 'ragi'. 'Ragi' is widely used for preparation of Malaysian food such as 'tapai', 'tempe', and bread. Issatchenkia banoiensis was first discovered from the litchi fruit borer in China (Thanh et al., 2003). Guava (Syzygium sp.) is a fruit which provides a sugar rich condition for yeast growth. Hanseniaspora sp. mostly can be found in various sources such as human, soil, water, fruits and sea creatures (Garc'iaMartos et al., 1999). Pichia guilliermondii is known to be the same genus as Pichia pastoris and utilizes methanol (a toxic material) as a carbon source. From the identification result, phylogenetic study was constructed to enable 
ancestral analysis of the yeast and ensure the GRAS status.

Using assimilation test, isolate WB was found to be from the genus Torulaspora. By $18 \mathrm{~S}$ identification it was identified as Saccharomyces sp. Both these genera are grouped in the Saccharomycetaceae family. However, ITS identification proved that it belonged to Saccharomycodes sp. within the family of Saccharomycodaceae. Since isolate WB was identified differently from species, genus and family, using the three identification strategies, there is a need to look at the next higher taxonomic rank. However, all strategies point to the Saccharomycetales order. A brief study was reported by Suh et al. (2006) regarding phylogenetics of Saccharomycetales order which belonged to ascomycete yeasts. Drug resistance gene has been widely used as a marker for selection of transformants in recombinant DNA technology. It was used in industrial yeast strains because these cells are diploid or aneuploid, lack a sexual cycle, and are prototrophic. Several of drug makers could be used for yeast selections and each of these markers has their specific limitations, in defining the suitable hosts and transformation efficiency (Hashida-Okado et al., 1998).

\section{CONCLUSIONS}

Yeast isolates from various sources were identified via rDNA ITS region generating four different yeast genus. Characterization studies were carried out for all the isolates. Drug resistant marker and lipolytic activity were determined for each isolate. Phylogenetic study of the isolates was conducted by using Neighbour-joining method. Since isolate WB showed lower similarity from BLAST result, it was chosen for further identification. ITS, 18S rDNA and biochemical test revealed that isolate WB could be grouped in a new family which belonged to Saccharomycetales order. New yeast expression system for this isolate WB could be developed by using phleomycin or geneticin as selection marker.

\section{Acknowledgements}

This project was supported financially by the Malaysia Genome Institute project number 07-05-MGI-GMB003 from the Ministry of Science, Technology and Innovation, Malaysia.

\section{REFERENCES}

Akada F (2002) Genetically modified industrial yeast ready for application. I Biosci Bioeng 94: 536-544.

Fadiloglu S, Erkmen O (2002) Effects of carbon and nitrogen sources on lipase production by Candida rugosa. Turkish J Eng Env Sci 26: 249-254.

Felsenstein J (1985) Confidence limits on phylogenies: An approach using the bootstrap. Evolution 39: 783-791.

Garc'1a-Martos P, Hern'andez-Molina JM, F'atima Gal'an JRR-H, Garc'1a-Agudo R, Palomo M Ju, Mira Je (1999) Isolation of Hanseniaspora uvarum (Kloeckera apiculata) in humans. Mycopathologia 144: $73-75$.
Gellissen G, Hollenberg CP (1997) Application of yeasts in gene expression studies: a comparison of Saccharomyces cerevisiae, Hansenula polymorpha and Kluyveromyces lactis - a review. Gene 190: 87-97.

Gellissen G, Kunze G, Gaillardin C, Cregg JM, Berardi E, Veenhuis M, Klei Ivd (2005) New yeast expression platforms based on methylotrophic Hansenula polymorpha and Pichia pastoris and on dimorphic Arxula adeninivorans and Yarrowia lipolytica - A comparison. FEMS Yeast Res 5: 1079-1096.

Hadfield C, Raina KK, Shashi-Menon K, Mount RC (1993) The expression and performance of cloned genes in yeasts. Mycol Res 97: 897-944.

Hashida-Okado T, Ogawa A, Kato I, Takesako K (1998) Transformation system for prototrophic industrial yeasts using the AUR1 gene as a dominant selection marker. FEBS Letters 425: 117-122.

Kaster KR, Burgett SG, lngolia TD (1984) Hygromycin B resistance as dominant selectable marker in yeast. Curr Genet 8: 353-358.

Korabecna M (2007) The Variability in the Fungal Ribosomal DNA (ITS1, ITS2, and 5.8 S rRNA Gene): Its Biological Meaning and Application in Medical Mycology. In Communicating Current Research and Educational Topics and Trends in Applied Microbiology, Méndez-Vilas A ed, pp 783-787. Formatex 2007.

Kwon D, Rhee J (1986) A simple and rapids colorimetric method for determination of free fatty acids for lipase assay. J Am Oil Chem Soc 63: 89-92.

Madzak C, Gaillardin C, Beckerich J-M (2004) Heterologous protein expression and secretion in the non-conventional yeast Yarrowia lipolytica: a review. J Biotechnol 109: 63-81.

Medlin L, Elwood HJ, Stickel S, Sogin ML (1988) The characterization of enzymatically amplified eukaryotic 16S-like rRNA-coding regions. Gene 71: 491-499.

Millerioux Y, Clastre M, Simkin AJ, Courdavault V, Marais E, Sibirny AA, Noe"1 T, Cre`che Jl, Giglioli-Guivarc'h N, Papon N (2011) Drug-resistant cassettes for the efficient transformation of Candida guilliermondii wild-type strains. FEMS Yeast Res 11: 457-463.

Pramateftaki PV, Lanaridis P, Typas MA (2000) Molecular identification of wine yeasts at species or strain level: a case study with strains from two vine-growing areas of Greece. I Appl Microbiol 89: 236-248.

Romanos MA, Scorer CA, Clare JJ (1992) Foreign gene expression in yeast: a review. Yeast 8: 423-488.

Saitou N, Nei M (1987) The neighbor-joining method: A new method for reconstructing phylogenetic trees. Mol Biol Evol 4: 406-425.

Shi X-L, Feng M-Q, Shi J, Shi Z-H, Zhong J, Zhou P (2007) Highlevel expression and purification of recombinant human catalase in Pichia pastoris. Protein Express Purif 54: 24-29.

Steinborn G, Wartmann T, Gellissen G, Kunze G (2007) Construction of an Arxula adeninivorans host-vector system based on trp1 complementation. J Biotechnol 127: 392-401.

Suh S-O, Kurtzman CP, Lachance M-A (2006) Phylogenetics of Saccharomycetales, the ascomycete yeasts. Mycologia 98: 1006-1017.

Sunga AJ, Tolstorukov I, Cregg JM (2008) Posttransformational vector amplification in the yeast Pichia pastoris. FEMS Yeast Res 8: 870-876.

Tamura K, Nei M, Kumar S (2004) Prospects for inferring very large phylogenies by using the neighbor-joining method. Proc Nat Acad S ci USA 101: 11030-11035.

Tamura K, Dudley J, Nei M, Kumar S (2007) MEGA4: Molecular Evolutionary Genetics Analysis (MEGA) software version 4.0. Mol Biol Evol 24: 1596-1599.

Thanh VN, Hai DA, Lachance M-A (2003) Issatchenkia hanoiensis, a new yeast species isolated from frass of the litchi fruit borer Conopomorpha cramerella Snellen. FEMS Yeast Res 4: 113-117.

Vakhlu J, Kour A (2006) Yeast lipases: enzyme purification, biochemical properties and gene cloning. Electron J Biotechnol 9.

Voronovsky, AY, V.Rohulya O, Abbas CA, Sibirny AA (2009) Development of strains of the thermotolerant yeast Hansenula polymorpha capable of alcoholic fermentation of starch and xylan. Metab Eng 11: $234-242$

Yamazaki T, Nakagawa Y, Hayakawa M, Iimura Y (2005) Phylogenetic position of the yeast strain Saccharomycodes sinensis IFO10111 ${ }^{\mathrm{T}}$. J Gen Appl Microbiol 51: 35-39. 